\title{
Establishing and Assessing a Textbook Collection
}

by Jennifer Hughes

As university faculty and librarians work together to find temporary and long-term solutions for providing affordable resources to students, many are exploring the benefits of open educational resources (OERs), inclusive resources in the library's collection, and textbook collections. Like many academic libraries, Coastal Carolina University's long-standing collection development policy specifically stated that textbooks would not be purchased by the library, and the only textbooks made available on course reserve were provided by the professor. However, when the university established internal grant funding to support student achievement and success, establishing a textbook collection seemed like an effective way to promote the need for affordable learning initiatives on campus while also providing a temporary solution that would be of immediate benefit to students. We were awarded $\$ 22,000$ to be used to establish a textbook collection over a two-year period (2018-20). In an effort to maximize the collection's impact on students, we decided to focus on purchasing textbooks for high-drop/fail/withdrawal (DFW) courses and core curriculum classes.

In order to begin our selection process, I first obtained lists of course DFW rates, core curriculum course designations, and course enrollment numbers. I then met with the campus bookstore manager to discuss affordable learning initiatives that would benefit our students. As part of that conversation, she agreed to send us a weekly list of all textbook adoptions for the library to consider purchasing.

Once we established our textbook wish list, individual titles were reviewed to determine purchase eligibility. Unfortunately, electronic textbook restrictions, online access codes, and personal workbooks made it impossible to purchase many of the books being used in the courses. That said, we decided it was best to purchase the textbooks we selected directly from our campus bookstore. Not only did it foster an environment of goodwill on campus but, by using her purchasing card, the acquisitions specialist was able to buy items directly from the shelves and eliminate shipping time.

Our collections department is critically understaffed, and we weighed the benefits of having the textbooks fully cataloged by our only cataloger over allowing multiple circulation staff to create brief cataloging records for the textbooks as if they were regular course reserves. Though that would have reduced the time for items to become shelf-ready, we decided to have our cataloger process the books and create full records. Not only would the full records improve discoverability, they would also provide us with more flexibility for updating the location during periods when the books no longer needed to be included in the textbook collection.

As evidence of the collection's popularity, the circulation stats for our course reserve and textbook collection can be used to show that there was an increase in usage after we began purchasing textbooks in 2018:

\begin{tabular}{|l|l|}
\hline $2017-18$ course reserves & 4314 checkouts \\
\hline $2018-19$ course reserves + textbook collection & 4916 checkouts \\
\hline $2019-20$ course reserves + textbook collection & 4368 checkouts (July-March only due to Covid-19) \\
\hline
\end{tabular}

Students' heavy utilization of the textbook collection in fall 2018 caught the eye of a local donor who gifted us an additional $\$ 18,000$ to expand this collection! For those funds, we accepted acquisi-

Jennifer Hughes is Associate University Librarian at Coastal Carolina University. 
tion requests from students through a whiteboard survey, asking them which textbooks we should buy. We received 150 responses in a two-week period! Although we did purchase many of these texts, we were also able to secure at least one-third of them by asking professors to provide a copy for course reserves. Many of the professors were surprised that their students were interested in having a copy of the text placed in the library, and, by reaching out to the professors, we were able to talk to them about the cost of textbooks, OERs, library resources, and other ways the library can support affordable learning. The conversations also prompted some faculty members to submit additional textbook acquisition requests from this fund.

In addition to the usage data, we obtained qualitative data from a whiteboard survey question that asked students how access to the textbooks benefited them. Students repeatedly reported how much money the library saved them! A few also commented about the convenience of having a book in the library so they didn't have to carry their own book to campus.

As a condition of the internal grant requirements, we also wanted to measure the collection's impact on student success by providing a list of students who checked out textbooks to our campus Office of Institutional Research. They found that students who checked out course textbooks from the library were less likely to fail or withdraw from their courses than those students who did not. Similar success was found at the course level as well. During the first semester of the textbook collection, our university saw a half-percent reduction in the DFW rate for all courses, but courses with material available in Kimbel Library saw a 3.12\% reduction.

\begin{tabular}{|l|l|l|}
\hline Fall 2018 & Total \# of grades & DFW rate \\
\hline Grades associated with checkouts & 461 & $16.92 \%$ \\
\hline Grades not associated with checkouts & 14,250 & $22.31 \%$ \\
\hline
\end{tabular}

\begin{tabular}{|l|l|}
\hline & \% change in DFW rate Fall 2017-Fall 2018 \\
\hline University-wide & $-.50 \%$ \\
\hline Courses with materials in textbook collection & $-3.12 \%$ \\
\hline
\end{tabular}

All of the data showed that our textbook collection was a success! It was heavily utilized, obtained great interest from students and donors, and promoted student success. But when I looked closer at our numbers, I was disheartened to learn that over half the textbooks we purchased were never checked out. When I compared the textbook circulation statistics to the use of newly purchased books in our general collection, however, I found that textbooks were utilized significantly more than the print books added to our general collection during the same time period.

\begin{tabular}{|l|l|l|l|}
\hline Collection & $\begin{array}{l}\text { Textbooks purchased with } \\
\text { grant funding (DFW; core } \\
\text { courses) }\end{array}$ & $\begin{array}{l}\text { Textbooks purchased with } \\
\text { donation funds (student } \\
\text { requested) }\end{array}$ & $\begin{array}{l}\text { Print books in the general } \\
\text { collection }\end{array}$ \\
\hline Spending 2018-20 & $\$ 20,767$ & $\$ 7,500$ & $\$ 59,869$ \\
\hline $\begin{array}{l}\text { \# of items purchased } \\
2018-20\end{array}$ & 223 & 77 & 968 \\
\hline Items with NO checkouts & $117(52 \%)$ & $54(70 \%)$ & $747(77 \%)$ \\
\hline
\end{tabular}




\begin{tabular}{|l|l|l|l|}
\hline Collection & $\begin{array}{l}\text { Textbooks purchased with } \\
\text { grant funding (DFW; core } \\
\text { courses) }\end{array}$ & $\begin{array}{l}\text { Textbooks purchased with } \\
\text { donation funds (student } \\
\text { requested) }\end{array}$ & $\begin{array}{l}\text { Print books in the general } \\
\text { collection }\end{array}$ \\
\hline \# of checkouts & 1465 & 179 & 359 \\
\hline $\begin{array}{l}\text { Cost per use (spending/ } \\
\text { checkouts) }\end{array}$ & $\$ 14.18$ & $\$ 41.90$ & $\$ 166.77$ \\
\hline
\end{tabular}

The use of the print collections is certainly something to further explore as we make purchase decisions and continue the conversations with professors about the use of course specific library resources. Given the high turnover in textbook adoptions for courses, it is not financially feasible to purchase the newest edition of textbooks each semester as a long-term strategy. However, it does seem that the textbook collection provides a temporary solution at the time of need for students. It also serves as a gateway for conversations throughout the campus about ways to make learning resources more affordable for students. 